\title{
Optimizing lung cancer MDT data for maximum clinical impact-a scoping literature review
}

\author{
Emily Stone ${ }^{1}$, Nicole Rankin ${ }^{2}$, David Currow ${ }^{3}$, Kwun M. Fong $^{4}$, Jane L. Phillips ${ }^{3}$, Tim Shaw ${ }^{5}$ \\ ${ }^{1}$ Department of Thoracic Medicine, St Vincent's Hospital Sydney, Kinghorn Cancer Centre, University of Sydney, Sydney, New South Wales, \\ Australia; ${ }^{2}$ Research in Implementation Science and e-Health (RISe), Faculty of Health Sciences, University of Sydney, Sydney, New South Wales, \\ Australia; ${ }^{3}$ IMPACCT, University of Technology Sydney, Ultimo, New South Wales, Australia; ${ }^{4}$ UQ Thoracic Research Centre and The Prince \\ Charles Hospital, Metro North Hospital and Health Service, Brisbane, QLD, Australia; ${ }^{5}$ Director of Research in Implementation Science and \\ eHealth Group (RISe), Charles Perkins Centre, University of Sydney, Sydney, New South Wales, Australia \\ Contributions: (I) Conception and design: All authors; (II) Administrative support: None; (III) Provision of study materials or patients: None; (IV) \\ Collection and assembly of data: All authors; (V) Data analysis and interpretation: All authors; (VI) Manuscript writing: All authors; (VII) Final \\ approval of manuscript: All authors. \\ Correspondence to: Emily Stone. Department of Thoracic Medicine, St Vincent's Hospital Sydney, Kinghorn Cancer Centre, University of Sydney, \\ Sydney, New South Wales, Australia. Email: emily.stone@svha.org.au.
}

\begin{abstract}
Multidisciplinary care in is widely recommended as best practice for lung cancer in many countries and jurisdictions. A number of studies suggest multidisciplinary care benefits patient outcomes, with analyses based on a range of data sources including national, state and local registries as well as multidisciplinary team meeting (MDT)-based data collections, often focused on different questions depending on data sources. MDT data collection and linkage are not standardized and not routine although data collection and feedback are specifically recommended by at least one statutory body. We performed a scoping review of current evidence for lung cancer MDT data collection and analysis, to identify discrete strategies through illustrative examples and to make recommendations for future approaches. Thirteen studies were identified that presented lung cancer MDT-related clinical outcomes, three included MDTs from multiple tumour streams while 10 studies focussed on lung cancer MDT meetings. Eleven studies measured the effect of MDT discussion on clinical outcomes of which eight were positive. Data sources included MDT records (3 studies), medical or hospital records (3 studies), institutional registries (5 studies) and state or national administrative datasets (6 studies), with some overlap. Examples of studies based on different data sources (local MDT, institutional registry, national registry) exemplified the different types of clinical research questions appropriate for each data source. While MDT data collection is not welldefined, the importance of clinical audit and data feedback and the potential for real-time analysis to improve outcomes deserve further investigation. Optimized datasets and linkage strategies are likely to maximize benefits for patients.
\end{abstract}

Keywords: Multidisciplinary team (MDT); multidisciplinary; tumor board; lung cancer; clinical data; database

Submitted Oct 23, 2019. Accepted for publication Jan 03, 2020.

doi: $10.21037 /$ tlcr.2020.01.02

View this article at: http://dx.doi.org/10.21037/tlcr.2020.01.02 


\section{Introduction}

Lung cancer multidisciplinary team (MDT) care (referring to multidisciplinary team meetings or tumour boards) is rapidly emerging as best practice cancer care, increasingly implemented across Australia, the United Kingdom, Europe and the United States. Presentation of cancer cases at MDT meetings is recommended by a number of professional bodies and international guidelines (1-5). Such meetings can require significant resources including attendance by specialist clinicians and allied health personnel, technological equipment, software and administrative support (6). A growing literature demonstrates potential benefits for lung cancer with MDT care associated with decreased premature mortality (7-11), treatment receipt and planning $(8,12,13)$. Two review studies have highlighted changes and improvements in management processes as well as clinical outcomes for people with lung cancer through MDT care $(14,15)$. The findings are based on disparate studies with data sources that include cancer registries and administrative datasets. Findings are often published some years after initial data collection, accounting for delays (appropriate for population-based registries) imposed by data quality requirements and access. Clinical data are not always routinely collected by MDTs, nor do they use standardised items, although many groups have published from their own datasets, which are often linked to local registries. A number have developed quality indicators to reflect quality of care, in particular for clinicians and health care providers (16-18). This manuscript reviews current knowledge of cancer MDT data collection and analysis with a focus on lung cancer, presents illustrative examples and recommends future directions.

Published studies provide constructive insights into the potential advantages and limitations of current MDTbased data collection. A number of teams have evaluated the impact of MDT practice on clinical outcomes, demonstrating associations between MDT care and treatment receipt (12), changes in treatment plans (13), adherence to international recommendations (19), accurate staging (15) and improved survival (7-11). A scoping review approach was chosen in order to document the evidence for MDT-based data collection and impact on outcomes and provide an overview of literature focus, according to previously published indications (20). Scoping reviews, as opposed to systematic reviews, allow mapping of literature, may be more inclusive and aim to determine the extent of evidence rather than synthesize existing evidence to answer specific questions (21). We have use the PRISMA-ScR checklist for scoping reviews to guide our approach (22).

Many health care settings typically collect clinical data into a range of repositories (23). These can include mandatory data collection, such as births and deaths, immunisation records and notifiable disease as well as curated information such as disease specific registries. Cancer data, including clinical lung cancer data, feed into jurisdictional registries in Australia and other similar health care settings with complex linkages and restricted access, appropriate for maintenance of privacy and data quality. However, many of these data collections are limited in their relevance to the busy, day-to-day practice of a working MDT. Questions about clinical outcomes such as timeliness of diagnosis and treatment, details of treatment and even survival for a cohort of patients cannot be quickly answered from these clinical registries. Delays imposed by perfectly reasonable access restrictions including human research ethics clearance and gaps in datasets (such as minimal treatment details in most state cancer registries) and their retrospective nature limit the usefulness of registry datasets for routine individual patient care. There is potential for individual MDTs to collect their own data to better answer questions about local treatment and outcomes although detailed recommendations for such MDT datasets have not yet been established. Questions remain about what information should be collected by MDTs, how to collect data from source systems, how to avoid duplication, how to best integrate into the datasets around MDT meetings such as local cancer registries, whether datasets should extend beyond single institutions and future unifying strategies at national levels.

In Australia there are differences between states and territories. Queensland has the most advanced MDT data integration system through Queensland Oncology Online (QOOL) (24), a government-funded program that draws upon data feeds from all state MDTs, with analyses and extracts available to registered members through an online dashboard. This system is being tested in other states but is not yet established nationwide. Although many MDTs do extract and review data, regular audit practices are not routine and the ease which with teams extract and analyse data varies between them. Data presentation also varies; some teams have published analyses of local data, some present regular audits and some do not engage in data analyses at all. Questions also remain about the utility of local, MDT-based data collection and analysis, whether it changes practice, helps with implementation of change and 


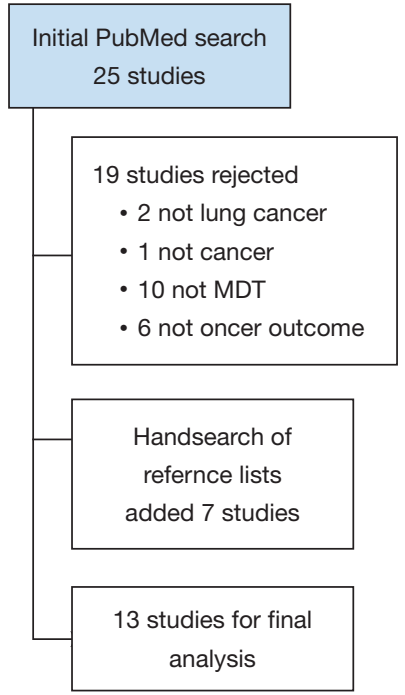

Figure 1 Results of literature search.

most importantly, whether it improves clinical outcomes.

\section{Aim}

To review current knowledge of lung cancer MDT data collection and analysis, present illustrative examples and recommend future directions.

\section{Methods}

A scoping review of the literature was performed. The protocol has not been previously published. English language publications in the National Library of Medicine database via the PubMed search engine with a focus on MDT-related clinical outcomes were searched for the previous decade, a time-period selected as likely high-yield for MDT publications relevant to up-to-date lung cancer management. The key words 'MDT' and 'lung cancer' and 'data' were used with no additional publications were identified using the search terms 'multi-disciplinary team', 'tumor board', 'audit' or 'analysis'. Papers were included if they had a primary focus on lung cancer multidisciplinary team care, referring MDT team meetings, or on MDT care across multiple tumour streams including lung cancer MDT meetings. Papers were excluded if they did not include lung cancer, MDT care and lung cancer outcomes. Reference lists of retrieved papers were hand-searched for additional relevant publications. MDT and study characteristics including country or origin, time period of data collection, tumour stream (if not dedicated lung cancer), number of subjects, impact of MDT on outcomes (if measured), data sources for MDT, nature of MDT dataset and presence or absence of digital data linkage were recorded for descriptive analysis.

\section{Results}

Publications with a focus on lung-cancer MDT-related clinical outcomes were identified. For the period 20092019, the search strategy identified 25 studies, 19 were excluded as not relevant to the study aim and 7 studies were added from hand-searching reference lists (see Figure 1 for search results). The studies are summarised in Table 1 . Thirteen studies were identified from six countries. The number of subjects ranged from 47 (single institutional study) to 129,052 from the National Lung Cancer Audit in the UK. Most studies were retrospective cohort analyses with one single centre prospective analysis of MDT discussion. The impact of MDT discussion was measured in $11 / 13$ studies and was positive in $8 / 11$ studies. Datasets included patient and tumour details, investigations, referral patterns, treatment and hospital details and, for the one study that investigated cancer centres, measures of process and outcomes. Most (10/13) studies focussed on lung cancer with the remaining $3 / 10$ investigating multiple tumour streams including lung cancer. Clinical outcomes included the impact of MDT presentation and care on treatment rates, survival, change in management plan preand post-survival, adherence to treatment-related guidelines and other factors such as rates of emergency department presentation. The interval between the end of the data period studied and the year of publication measured approximately $53 \pm 32$ months (average $\pm \mathrm{SD}$ ).

Data sources differed between the studies with some overlap as shown in Table 1. Three studies used MDT records $(13,25,26)$, three used medical records $(13,26,27)$, five used institutional registries $(7,10-12,27)$ and six used state or national administrative datasets or registries $(8,9,27-30)$. Of the studies identified, 10/13 used data linkage, registry and/ or administrative data (7-12,27-30) with $3 / 13$ basing their analyses on MDT or medical records $(13,25,26)$. The three largest studies (with $>10,000$ cases) based their analyses on large, national registry and administrative datasets $(9,28,30)$. Differences in outcomes related to MDT presentation were identified in the 10/13 studies that used data linkage and in $1 / 3$ that did not (13). It is premature to ascertain any pattern between findings of positive impact of MDT and 
Table 1 Studies included in the review for impact of MDT-related data on lung cancer clinicaloutco

\begin{tabular}{|c|c|c|c|c|c|c|c|c|c|}
\hline Reference & Country & Data period & Study design & $\begin{array}{l}\text { Tumour stream } \\
\text { studied }\end{array}$ & $\mathrm{N}$ & Impact of MDT & Data sources & Minimum dataset & Digital data linkage \\
\hline $\begin{array}{l}\text { Nadaraja } 2019 \\
(25)\end{array}$ & Denmark & $\begin{array}{c}\text { Jan 2016-Jun } \\
2018\end{array}$ & $\begin{array}{l}\text { Single centre open } \mathrm{RCT} \text {; } \\
\text { randomization to a geriatric screening } \\
\text { tool }\end{array}$ & Multiple & 151 & Not measured & $\begin{array}{l}\text { MDT decision recorded by } \\
\text { treating oncologist }\end{array}$ & $\begin{array}{l}\text { Patient details; CGA* } \\
\text { data; MDT results; QOL } \\
\text { questionnaire }\end{array}$ & None \\
\hline $\begin{array}{l}\text { Galata } 2019 \\
(26)\end{array}$ & Germany & $\begin{array}{l}\text { Feb 2017-Jul } \\
\quad 2017\end{array}$ & $\begin{array}{l}\text { Prospective single-centre analysis } \\
\text { of consecutive patients discussed at } \\
\text { MDT }\end{array}$ & Multiple & 47 & Not measured & $\begin{array}{l}\text { MDT registration forms; nursing } \\
\text { and medical records }\end{array}$ & $\begin{array}{l}\text { Patient details; tumour } \\
\text { details }\end{array}$ & None \\
\hline Stone 2018 (11) & Australia & $\begin{array}{l}\text { Jan } 2006- \\
\text { Dec } 2012\end{array}$ & $\begin{array}{l}\text { Retrospective single centre analysis } \\
\text { of all lung cancer patients }\end{array}$ & Lung & 1,197 & Improved survival & Institutional cancer registry & $\begin{array}{l}\text { Patient details; tumour } \\
\text { details }\end{array}$ & $\begin{array}{l}\text { MDT database linked to } \\
\text { institutional cancer registry }\end{array}$ \\
\hline $\begin{array}{l}\text { Bilfinger } 2018 \\
(10)\end{array}$ & USA & 2002-2016 & $\begin{array}{l}\text { Retrospective single centre analysis } \\
\text { of all lung cancer patients }\end{array}$ & Lung & 4,271 & Improved survival & Institutional cancer registry & $\begin{array}{l}\text { Patient details; tumour } \\
\text { details; treatment details }\end{array}$ & $\begin{array}{l}\text { MDT database linked to } \\
\text { institutional cancer registry }\end{array}$ \\
\hline Ung 2016 (13) & Australia & $\begin{array}{l}\text { Mar-May } \\
2011\end{array}$ & $\begin{array}{c}\text { Retrospective single-centre analysis } \\
\text { of consecutive lung cancer patients } \\
\text { discussed at MDT }\end{array}$ & Lung & 68 & $\begin{array}{l}\text { Change in treatment } \\
\text { plan }\end{array}$ & MDT records; hospital records & $\begin{array}{l}\text { Patient details; tumour } \\
\text { details; referral patterns }\end{array}$ & None \\
\hline Boxer 2016 (27) & Australia & $\begin{array}{l}\text { Dec 2005- } \\
\text { Dec } 2010\end{array}$ & $\begin{array}{c}\text { Retrospective single centre analysis } \\
\text { of new lung cancer patients } \\
\text { discussed at MDT }\end{array}$ & Lung & 808 & $\begin{array}{l}\text { No change in } \\
\text { adherence to } \\
\text { treatment guidelines }\end{array}$ & $\begin{array}{l}\text { Institutional cancer registry; State } \\
\text { Births, Deaths and Marriages } \\
\text { registry; electronic medical record }\end{array}$ & $\begin{array}{l}\text { Patient details; tumour } \\
\text { details; staging } \\
\text { investigations; referral } \\
\text { patterns; treatment } \\
\text { recommendations }\end{array}$ & $\begin{array}{l}\text { Data extracted from } \\
\text { institutional cancer registry }\end{array}$ \\
\hline Pan 2015 (9) & Taiwan & 2005-2010 & $\begin{array}{l}\text { Retrospective analysis of national } \\
\text { cohort of new lung cancer patients }\end{array}$ & Lung & 32,569 & $\begin{array}{l}\text { Improved survival } \\
\text { stages III and IV } \\
\text { NSCLC }\end{array}$ & $\begin{array}{l}\text { National Cancer Registry; } \\
\text { National Health Insurance } \\
\text { Research Database; National } \\
\text { Cause of Death data }\end{array}$ & $\begin{array}{l}\text { Patient details; tumour } \\
\text { details; hospital details }\end{array}$ & Linkage of 3 national registries \\
\hline Wang 2014 (28) & Taiwan & 2005-2007 & $\begin{array}{l}\text { Retrospective, longitudinal cohort } \\
\text { study of lung cancer patients }\end{array}$ & Lung & 22,817 & $\begin{array}{l}\text { Reduced emergency } \\
\text { department visits }\end{array}$ & $\begin{array}{l}\text { National Health Insurance } \\
\text { Research Database }\end{array}$ & $\begin{array}{l}\text { Patient details; hospital } \\
\text { details; referral patterns }\end{array}$ & $\begin{array}{l}\text { Data extracted from national } \\
\text { registry }\end{array}$ \\
\hline $\begin{array}{l}\text { Mitchell } 2013 \\
\text { (8) }\end{array}$ & Australia & $\begin{array}{c}\text { Jan 2003-Jun } \\
2003\end{array}$ & $\begin{array}{l}\text { Retrospective analysis of all new } \\
\text { diagnoses of lung cancer }\end{array}$ & Lung & 841 & $\begin{array}{l}\text { Better treatment } \\
\text { receipt; improved } \\
\text { survival }\end{array}$ & Victorian Cancer Registry & $\begin{array}{l}\text { Patient details; tumour } \\
\text { details; treatment details }\end{array}$ & $\begin{array}{l}\text { Data extracted from state } \\
\text { registry }\end{array}$ \\
\hline $\begin{array}{l}\text { Keating } 2013 \\
\text { (29) }\end{array}$ & USA & 2001-2004 & Survey of $\mathrm{VA}^{\star \star \star}$ medical centres & Multiple & $\begin{array}{c}138 \\
\text { facilities }\end{array}$ & No change & $\begin{array}{l}\text { VA registry; VA administrative } \\
\text { data; National Death Index; } \\
\text { survey }\end{array}$ & $\begin{array}{l}\text { Measures of cancer care, } \\
\text { processes and outcomes }\end{array}$ & Linkage of 3 registries \\
\hline $\begin{array}{l}\text { Beckett } 2012 \\
(30)\end{array}$ & UK & 2006-2010 & $\begin{array}{l}\text { Retrospective analysis of all NSCLC } \\
\text { cases submitted to NLCA }{ }^{\dagger} \text { (England) }\end{array}$ & Lung & 129,052 & $\begin{array}{l}\text { No impact of volume } \\
\text { of MDT case-load }\end{array}$ & NLCA (England only) & $\begin{array}{l}\text { MDT discussion }{ }^{\star \star} \text { stratified } \\
\text { by case-load; patient details; } \\
\text { tumour details; treatment } \\
\text { details }\end{array}$ & $\begin{array}{l}\text { Data extracted from national } \\
\text { registry (audit) }\end{array}$ \\
\hline Boxer 2011 (12) & Australia & $\begin{array}{l}\text { Dec 2005- } \\
\text { Dec } 2008\end{array}$ & $\begin{array}{l}\text { Retrospective single centre analysis } \\
\text { of new lung cancer patients }\end{array}$ & Lung & 988 & $\begin{array}{l}\text { Better treatment } \\
\text { receipt }\end{array}$ & Institutional cancer registry & $\begin{array}{l}\text { Patient details; tumour } \\
\text { details; treatment details }\end{array}$ & $\begin{array}{l}\text { MDT database linked to } \\
\text { institutional cancer registry }\end{array}$ \\
\hline $\begin{array}{l}\text { Bydder } 2009 \\
\text { (7) }\end{array}$ & Australia & $\begin{array}{c}\text { Jan 2006-Mar } \\
2008\end{array}$ & $\begin{array}{c}\text { Retrospective single centre analysis } \\
\text { of all patients with histological } \\
\text { NSCLC }\end{array}$ & Lung & 98 & Improved survival & Institutional cancer registry & $\begin{array}{l}\text { Patient details; tumour } \\
\text { details; treatment details }\end{array}$ & $\begin{array}{l}\text { Data extracted from } \\
\text { institutional cancer registry }\end{array}$ \\
\hline
\end{tabular}

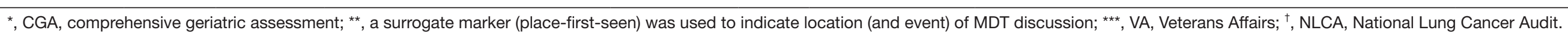


data sources used (local $v s$. registry).

Closer review of several of these papers better illustrates how the MDT analyses were performed and the types of questions answerable from different data sources. We have selected three studies that demonstrated a positive impact and that used different data sources: a small singleinstitution study that investigated details of MDT practice through analyses of local data, a large single-institution study that used institutional cancer registry data for MDTrelated survival analysis and a large, countrywide Taiwanese study that interrogated linked administrative datasets to evaluate MDT-related survival across a nationally-based cohort.

\section{Single-institutional study based on local data}

The prospective cohort study by Ung et al. (13) derives information from consecutively enrolled cases presented to the institutional lung cancer MDT over an 11-week period. One investigator extracted clinical information and a proposed management plan from the electronic form routinely submitted to the MDT and contacted clinicians directly if data were missing. Cases were excluded if critical data (the pre-MDT management plan, critical clinical information such as staging) were not available. A second investigator, blinded to the pre-MDT plan, collected MDT recommendations. Subsequent hospital record review several months later was performed to check rates of implementation of the MDT recommendations. Sixty-eight cases were recruited, with 13 excluded due to missing data. Fifty-five cases were analysed. This study is characterized by detailed, personalized collection of data with individualized follow up of a small study sample for missing information and asks particular practice questions suitable for smallscale study design that may not be answerable from larger datasets.

\section{Larger, single institutional study based on local registry data}

The longitudinal cohort study by Bilfinger et al. (10) is the largest of the single-institution studies that reviewed and obtained data from an institutional cancer registry over a 15 -year period. The study cross-linked the cancer registry with the local Lung Cancer Evaluation Centre MDT database, which allowed the investigators to identify 1,956 lung MDT cases (defined by at least one clinical encounter with MDT clinicians and MDT presentation) and 2,315
"non-MDT" cases. Data drawn from the registry included patient and tumour characteristics although not performance status, details of prior therapy or date of first detection. The two groups were compared using standard statistical methods, were stratified by date (of entry into the registry) to minimize confounding for improvements in survival over time and propensity-matched analyses were used to minimize selection bias. The risk of crossover between groups was addressed. This study used a retrospective registry cohort to analyse lung cancer outcomes and related them to MDT care, acknowledging missing clinical details and using standard, although imperfect (31) statistical methods to account for confounding factors. The primary aim was to compare survival between the two groups, a question that requires information and methods not likely including in local MDT data collections such as longerterm outcomes and links to administrative datasets.

\section{Large, national analysis based on linked national administrative datasets}

The retrospective, nationwide cohort study by Pan et al. (9) analyses data newly diagnosed lung cancer cases recorded in the Taiwanese national cancer registry during a five-year period. The study combined data from three administrative datasets: the Taiwan Cancer Registry; the National Health Insurance Research Database; and, the Cause of Death Statistics Database, to extract information for 32,569 cases of non-small cell lung cancer (NSCLC) who had received treatment in the first year. The study analysed the cohort for participation in MDT and related this to a number of patent and health service characteristics using propensity score analysis to balance the MDT and non-MDT groups. Similar to the Bilfinger study above, this study aimed primarily to determine the impact of MDT care on survival for each stage of NSCLC and detected a benefit for stages III and IV but not for earlier stage disease although the distinction between the two groups was small. That a difference was found at all may possibly be due to the large size of the cohort and depend therefore on the health system infrastructure that collects, stores and links relevant information, including MDT participation, at a national scale.

\section{Discussion}

In this review article, we have found diversity in lung cancer MDT reporting and in the sophistication of 
data linkage across sources, with impediments such as time delays that compete with clinical needs for close to real-time review. In many settings, MDT meetings have developed as primarily clinical meetings with subsequent introduction of rules, expectations and standards. Current published guidelines from statutory bodies such as the NHS National Cancer Action Team (32) and the American College of Surgeons (33) describe expected practices and refer generally, but not specifically to aspects of MDT or tumour board cancer data collection, audit and analysis. The more specific recommendations from the NHS NCAT and include reference to resources, high impact data, national mandated data sets data feedback to teams, audit and review activities and patient input, although do not prescribe detailed MDT datasets. The NCAT recommendations for data collection, analysis and audit of outcomes cover the following points:

(I) Data collection resources are available to the MDT;

(II) Key information that directly affects treatment decisions (such as stage, performance status etc) is collected by the MDT;

(III) Mandated national datasets are populated before or during MDT meetings;

(IV) Data collected during MDT meetings is analysed and subject to feedback;

(V) The MDT participates in audits of processes and outcomes and changes practice where necessary;

(VI) MDTs incorporate clinical outcomes data made available through (e.g.) peer review and clinical reference groups;

(VII) Patients experience surveys include questions on MDTs and MDTs respond to patient feedback.

Our group has published an optimal minimum dataset for lung cancer MDTs (34) developed through a modified Delphi consensus method and the International Consortium for Health Outcomes Measurement has defined a larger dataset based on patient-centred outcomes (35). To our knowledge, no other recommended datasets have been published. A UK study that surveyed over 1,200 MDT members for views on streamlining discussion (36) infers the need for MDT data although does not specify data items for collection. In this study, survey responses favoured auditing patients placed on protocolized management pathways, raised concerns about the effect of streamlining on quality and safety of care and supported collecting evidence on the impact of MDT innovations on clinical outcomes to overcome limitations of existing evidence. One of the most comprehensive data environments for MDTs is based in the Australian state of Queensland where Cancer Alliance Queensland (37) hosts QOOL (38), a platform that integrates data from various sources with an emphasis on the provision of "just-in-time" clinical information (39) to clinicians and MDTs for clinical care and research. Integration of MDT data through the QOOL platform with a focus on rapid access to timely information has the potential for "real-time" impact on clinical decisions. At the time of writing, QOOL is used by 67 MDTs across Queensland (38) and is in development for the state of Victoria (40).

The impact of MDT care on lung cancer outcomes appears promising. Studies included in this review suggested improvements across clinical outcomes including survival, treatment receipt and changes in treatment plans postMDT presentation. In this issue, Heinke and Vinod (41) present a more extensive evaluation of the effects of MDT care on clinical lung cancer outcomes including survival, treatment details, referral patterns and patientreported outcomes. Information transfer from MDTs to large collections can support cancer registries even at national level such as the UK NLCA, which can then report on outcomes and quality of care as in its most recent 2018 report $(41,42)$. The institution of the NLCA and regular reporting, supported by these data, have seen an improvement in outcomes for lung cancer including most recently, an increase in tissue confirmation in early stage disease, in systemic therapy for both NSCLC and small cell lung cancer (SCLC) and in surgical rates (42). MDT data have the potential to support research, as is shown by the series of papers reviewed in this manuscript, as well as team-based quality assurance activities. However, many questions persist about the best way to implement more comprehensive MDT data collection including the specifics of datasets, resources required, strategies for feedback and how to link datasets effectively.

The datasets analysed for these studies all differ, ranging from local clinical registries to large administrative datasets. In some settings data collected by MDTs may contribute to larger datasets and subsequent analyses. In many cases, clinicians do not have ready access to these larger, population-based datasets, which themselves are not designed to provide immediate, real-time insights into patient outcomes. The benefits of "knowing your own data", include quality assurance and improvement activities, benchmarking against guidelines and peers and other centres and development of research questions. The proliferation of MDT-related research papers over recent 
years indicates a strong interest in MDT practice. Research from our group has identified positive responses from MDT clinicians to modelled data feedback, representing their own clinical cohorts (43).

The effects of real-time clinical data feedback on practice and outcomes in lung cancer MDT care remain enticing, but as yet not established. The workings and impact of QOOL have not yet been published. National lung cancer audits such as in the UK above, Denmark (44) and the Netherlands $(16,45)$ demonstrate the effects of systems that include institutional data feeds into national registries, portals for feedback and subsequent benchmarking. Smaller scale studies have tested details of audit and feedback to clinicians both in lung cancer $(43,46)$ and other fields $(47)$ but there is little if any (to our knowledge) literature on the effects of real-time, clinical data feedback to lung cancer MDTs on clinical outcomes. Cancer outcomes data are often delayed, even in this series of papers with an average of over four years between the data collection period and publication of the paper. Epidemiological datasets take time to clean, privacy laws delay access and need for accuracy and completeness delays reporting. The use of links to administrative datasets for clinical practice and research carries appeal (large amounts of data, population-based relevance) but also has limitations, best summarised in a review of linked data in nephrology in Australia but with broadly applicable concepts-limitations of content for routinely collected data (timing, quality, completeness, missing data such as treatment details) and delays and access barriers imposed by "concerns about data ownership privacy and confidentiality" (23).

The combination of digitized health care data and increasingly accessible systems such as QOOL can give clinicians unprecedented access to vast pools of data. However, much of this information risks sitting unused for clinical practice improvements (as opposed to use for health services research, for example) unless it is relevant, timely and informative for clinical purposes. MDT data collection is not yet ideal. We do not have a clear record of what information is currently collected by most MDTs, or how it is stored and analysed. We do not have established standard datasets for MDTs, although several have been published. There may be room for MDT data integration into national lung cancer clinical registries. Limited data suggest that MDT care has a positive impact on lung cancer outcomes and access to registry data may allow analysis of larger cohorts across longer time frames. The benefits of routinely collected, standardized MDT data collections warrant exploration and may include better benchmarking, evaluation of key indicators and improvements in outcomes. The benefits of data linkage (which may also impair currency of data) may include larger study cohorts, more rapid access to data such as survival and better evaluation of quality of care. For MDT clinicians, the goal persistsrapid, easy access to timely and comprehensive information that leads to practice change and better outcomes for patients.

\section{Conclusions and recommendations}

Multidisciplinary team care in lung cancer is broadly supported by international clinical groups and statutory bodies and may improve patient outcomes. Integration of prompt information feedback into routine MDT operation has not been widely studied and the collection of clinical data by lung cancer MDTs has not yet been well-defined or implemented. Standardized datasets, integrated real-time platforms and appropriate data linkage all have potential to optimize the quality and relevance of MDT data collections, which may lead to improvements in benchmarking, quality activities and even patient outcomes.

\section{Acknowledgments}

Funding: Dr. Stone was supported in this research by the St Vincent's Centre for Applied Medical Research (AMR) and the St Vincent's Clinic Foundation AMR Clinician Buy-Out Grant.

\section{Footnote}

Provenance and Peer Review: This article was commissioned by the Guest Editor (Emily Stone) for the series "Lung Cancer Multidisciplinary Care" published in Translational Lung Cancer Research. The article was sent for external peer review organized by the Guest Editor and the editorial office.

Conflicts of Interest: The series "Lung Cancer Multidisciplinary Care" was commissioned by the editorial office without any funding or sponsorship. ES served as the unpaid Guest Editor of the series and serves as an unpaid editorial board member of Translational Lung Cancer Research from Nov 2018 to Nov 2020. The authors have no other conflicts of 
interest to declare.

Ethical Statement: The authors are accountable for all aspects of the work in ensuring that questions related to the accuracy or integrity of any part of the work are appropriately investigated and resolved.

Open Access Statement: This is an Open Access article distributed in accordance with the Creative Commons Attribution-NonCommercial-NoDerivs 4.0 International License (CC BY-NC-ND 4.0), which permits the noncommercial replication and distribution of the article with the strict proviso that no changes or edits are made and the original work is properly cited (including links to both the formal publication through the relevant DOI and the license). See: https://creativecommons.org/licenses/by-nc-nd/4.0/.

\section{References}

1. Cancer Institute NSW. NSW Cancer Plan 2016 [Internet]. 2016 [cited 2017 Jul 20]. Available online: https:// www.cancer.nsw.gov.au/getattachment/cancer-plan/ CancerPlan2016_Web.pdf?lang=en-AU

2. Independent Cancer Task Force. Achieving WorldClass Cancer Outcomes: A Strategy for England 20152020 [Internet]. Available online: https://www.england. nhs.uk/wp-content/uploads/2017/10/national-cancertransformation-programme-2016-17-progress.pdf

3. Postmus PE, Kerr KM, Oudkerk M, et al. Early and locally advanced non-small-cell lung cancer (NSCLC): ESMO Clinical Practice Guidelines for diagnosis, treatment and follow-up. Ann Oncol Off J Eur Soc Med Oncol 2017;28:iv1-21.

4. Planchard D, Popat S, Kerr K, et al. Metastatic non-small cell lung cancer: ESMO Clinical Practice Guidelines for diagnosis, treatment and follow-up. Ann Oncol 2019;30:863-70.

5. NCCN Clinical Practice Guidelines in Oncology NonSmall Cell Lung Cancer Version 7. 2019 - August 30, 2019 [Internet]. nccn.org; Available online: https://www.nccn. org/professionals/physician_gls/pdf/nscl_blocks.pdf

6. Lamprell K, Arnolda G, Delaney GP, et al. The challenge of putting principles into practice: Resource tensions and real-world constraints in multidisciplinary oncology team meetings. Asia Pac J Clin Oncol 2019;15:199-207.

7. Bydder S, Nowak A, Marion K, et al. The impact of case discussion at a multidisciplinary team meeting on the treatment and survival of patients with inoperable non- small cell lung cancer. Intern Med J 2009;39:838-41.

8. Mitchell PLR, Thursfield VJ, Ball DL, et al. Lung cancer in Victoria: are we making progress? Med J Aust 2013;199:674-9.

9. Pan CC, Kung PT, Wang YH, et al. Effects of Multidisciplinary Team Care on the Survival of Patients with Different Stages of Non-Small Cell Lung Cancer: A National Cohort Study. PLoS One 2015;10:e0126547.

10. Bilfinger TV, Albano D, Perwaiz M, et al. Survival Outcomes Among Lung Cancer Patients Treated Using a Multidisciplinary Team Approach. Clin Lung Cancer 2018;19:346-351.

11. Stone E, Rankin N, Kerr S, et al. Does presentation at multidisciplinary team meetings improve lung cancer survival? Findings from a consecutive cohort study. Lung Cancer 2018;124:199-204.

12. Boxer MM, Vinod SK, Shafiq J, et al. Do multidisciplinary team meetings make a difference in the management of lung cancer? Cancer 2011;117:5112-20.

13. Ung KA, Campbell BA, Duplan D, et al. Impact of the lung oncology multidisciplinary team meetings on the management of patients with cancer. Asia Pac J Clin Oncol 2016;12:e298-304.

14. Prades J, Remue E, van Hoof E, et al. Is it worth reorganising cancer services on the basis of multidisciplinary teams (MDTs)? A systematic review of the objectives and organisation of MDTs and their impact on patient outcomes. Health Policy 2015;119:464-74.

15. Pillay B, Wootten AC, Crowe H, et al. The impact of multidisciplinary team meetings on patient assessment, management and outcomes in oncology settings: A systematic review of the literature. Cancer Treat Rev 2016;42:56-72.

16. Beck N, Hoeijmakers F, Wiegman EM, et al. Lessons learned from the Dutch Institute for Clinical Auditing: the Dutch model for quality assurance in lung cancer treatment. J Thorac Dis 2018;10:S3472-85.

17. Wang X, Su S, Li S, et al. Development of quality indicators for non-small cell lung cancer care: a first step toward assessing and improving quality of cancer care in China. BMC Cancer 2017;17:603.

18. Brønserud MM, Iachina M, Green A, et al. Patient reported outcome data as performance indicators in surgically treated lung cancer patients. Lung Cancer 2019;130:143-8.

19. Conron M, Phuah S, Steinfort D, et al. Analysis of multidisciplinary lung cancer practice. Intern Med J 2007;37:18-25. 
20. Munn Z, Peters MDJ, Stern C, et al. Systematic review or scoping review? Guidance for authors when choosing between a systematic or scoping review approach. BMC Med Res Methodol 2018;18:143.

21. Peters MDJ, Godfrey CM, Khalil H, et al. Guidance for conducting systematic scoping reviews. Int J Evid Based Healthc 2015;13:141-6.

22. Tricco AC, Lillie E, Zarin W, et al. PRISMA Extension for Scoping Reviews (PRISMA-ScR): Checklist and Explanation. Ann Intern Med 2018;169:467-73.

23. Kotwal S, Webster AC, Cass A, et al. A review of linked health data in Australian nephrology. Nephrology (Carlton) 2016;21:457-66.

24. QOOL [Internet]. [cited 2019 Apr 25]. Available online: https://cancerallianceqld.health.qld.gov.au/QOOLHelp/

25. Nadaraja S, Matzen LE, Jørgensen TL, et al. The impact of comprehensive geriatric assessment for optimal treatment of older patients with cancer: A randomized parallel-group clinical trial. J Geriatr Oncol 2020;11:488-495.

26. Galata C, Wimmer E, Kasper B, et al. Multidisciplinary Tumor Board Recommendations for Oligometastatic Malignancies: A Prospective Single-Center Analysis. Oncol Res Treat 2019;42:87-94.

27. Boxer MM, Duggan KJ, Descallar J, et al. Do patients discussed at a lung cancer multidisciplinary team meeting receive guideline-recommended treatment? Asia Pac J Clin Oncol 2016;12:52-60.

28. Wang SM, Kung PT, Wang YH, et al. Effects of Multidisciplinary Team Care on Utilization of Emergency Care for Patients With Lung Cancer. Am J Manag Care 2014;20:e353-64.

29. Keating NL, Landrum MB, Lamont EB, et al. Tumor boards and the quality of cancer care. J Natl Cancer Inst 2013;105:113-21.

30. Beckett P, Woolhouse I. Inequalities in outcomes for non-small cell lung cancer: the role of the MDT. Thorax 2012;67:926-7; author reply 927.

31. Yao XI, Wang X, Speicher PJ, et al. Reporting and Guidelines in Propensity Score Analysis: A Systematic Review of Cancer and Cancer Surgical Studies. J Natl Cancer Inst 2017. doi: 10.1093/jnci/djw323.

32. National Health System. National Cancer Action Team NHS. The characteristics of an effective multidisciplinary team (MDT) [Internet]. National Cancer Registration and Analysis Service (NCRAS) Public Health England Chief Knowledge Officer Directorate Zone D, 2nd Floor, Skipton House London, SE1 6LH; 2010 [cited 2017 Jul
21]. Available online: https://www.google.com/url?sa=t\&rc $\mathrm{t}=\mathrm{j} \& \mathrm{q}=\&$ esrc $=\mathrm{s} \&$ source $=$ web\& $\mathrm{cd}=3$ \&ved=2ahUKEwjjvoq A0rHnAhXFmuYKHYybDnUQFjACegQIDRAE\&url=ht tp\%3A\%2F\%2Fwww.ncin.org.uk\%2Fview\%3Frid\%3D13 6\&usg=AOvVaw214j7w2aP1E3RCA5iK0TvK

33. Commission on Cancer. CANCER PROGRAM STANDARDS: Ensuring Patient-Centered Care [Internet]. 2016. Available online: https://www.facs.org/-/ media/files/quality-programs/cancer/coc/2016-cocstandards-manual_interactive-pdf.ashx?la=en

34. Stone E, Rankin N, Phillips J, et al. Consensus minimum data set for lung cancer multidisciplinary teams: Results of a Delphi process. Respirology 2018;23:927-34.

35. Mak KS, van Bommel ACM, Stowell C, et al. Defining a standard set of patient-centred outcomes for lung cancer. Eur Respir J 2016;48:852-60.

36. Hoinville L, Taylor C, Zasada M, et al. Improving the effectiveness of cancer multidisciplinary team meetings: analysis of a national survey of MDT members' opinions about streamlining patient discussions. BMJ Open Qual 2019;8:e000631.

37. Cancer Alliance Queensland [Internet]. [cited 2019 Sep 26]. Available online: https://cancerallianceqld.health.qld. gov.au/

38. Cancer Alliance Queensland QOOL [Internet]. [cited 2019 Sep 26]. Available online: https://cancerallianceqld. health.qld.gov.au/applications/qool/

39. Cancer Alliance Queensland. QOOL Introduction [Internet]. [cited 2019 Sep 26]. Available online: https:// cancerallianceqld.health.qld.gov.au/QOOLHelp/

40. Services D of H\& H. QOOL-VIC Multidisciplinary Team Meeting Management Software [Internet]. [cited 2019 Sep 26]. Available online: https://www2.health.vic. gov.au:443/about/health-strategies/cancer-care/cancerprojects/qool-vic

41. Heinke, MY, Vinod SK. A review on the impact of Lung Cancer Multidisciplinary Care on patient outcomes. Transl Lung Cancer Res 2019. doi: 10.21037/tlcr.2019.11.03.

42. National Lung Cancer Audit (NLCA) annual report 2018 [Internet]. RCP London. 2019 [cited 2019 Sep 26]. Available online: https://www.rcplondon.ac.uk/ projects/outputs/national-lung-cancer-audit-nlca-annualreport-2018

43. Stone E, Rankin N, Vinod S, et al. Clinical Impact of Data Feedback at Lung Cancer Multidisciplinary Team Meetings. Asia Pac J Clin Oncol 2020 ;16:45-55.

44. Jakobsen E, Green A, Oesterlind K, et al. Nationwide quality improvement in lung cancer care: the role of the 
Danish Lung Cancer Group and Registry. J Thorac Oncol 2013;8:1238-47.

45. Ten Berge M, Beck N, Heineman DJ, et al. Dutch Lung Surgery Audit: A National Audit Comprising Lung and Thoracic Surgery Patients. Ann Thorac Surg 2018;106:390-7.

46. Jazieh A, Alkaiyat MO, Ali Y, et al. Improving adherence to lung cancer guidelines: a quality improvement project that uses chart review, audit and feedback approach. BMJ Open Qual 2019;8:e000436.

47. Petit-Monéger A, Saillour-Glénisson F, NouetteGaulain K, et al. Comparing Graphical Formats for Feedback of Clinical Practice Data. A Multicenter Study among Anesthesiologists in France. Methods Inf Med 2017;56:28-36.

Cite this article as: Stone E, Rankin N, Currow D, Fong KM, Phillips JL, Shaw T. Optimizing lung cancer MDT data for maximum clinical impact-a scoping literature review. Transl Lung Cancer Res 2020;9(4):1629-1638. doi: 10.21037/tlcr.2020.01.02 